\title{
Characterization of MCF-12A cell phenotype, response to estrogens, and growth in $3 \mathrm{D}$
}

\author{
Michael F. Sweeney ${ }^{1}$, Carlos Sonnenschein ${ }^{2}$ and Ana M. Soto ${ }^{2^{*}}$
}

\begin{abstract}
Background: Three-dimensional cultures of mammary epithelial cells allow for biologically-relevant studies of the development of the mammary gland in rodents and humans under normal and pathological conditions, like carcinogenesis. Under these conditions, mammotropic hormones play significant roles in tissue morphogenesis. Therefore, a system that recreates the normal, hormonally responsive epithelium would be a valuable tool to study the normal state and its transition to carcinogenesis. MCF-12A cells have been claimed to be non-tumorigenic mammary epithelial cells with reported sensitivity to estrogens. In this study, we aimed at characterizing MCF-12A cells for use in a hormone-responsive 3D culture system to determine their usefulness as a tool to identify normal and abnormal microenvironmental cues.
\end{abstract}

Methods: MCF-12A cells were single-cell cloned in order to investigate their heterogeneous makeup. The parental cells were then treated with estradiol to investigate proliferative and transcriptional responses through the estrogen receptor alpha. Finally, parental cells and epithelial-like cell-derived clones were seeded in rat-tail collagen I to profile the morphogenesis of multicellular 3D structures. The resultant structures were then analyzed using unsupervised morphometric analysis.

Results: MCF-12A cells consist of epithelial-like colonies which shed elongated, freely growing cells on the colony's edges. The cells express E-cadherin as well as mesenchymal vimentin but do not express markers associated with myoepithelial cells or fibroblasts. Treatment with estradiol does not affect either the proliferation rate or the induction of gene expression in MCF-12A cells. Parental MCF-12A cells form acini, solid spheres and elongated branching ducts when grown in rat-tail collagen type I matrix, the geometries and distribution of which are altered following the removal of fibroblast-like cells.

Conclusions: MCF-12A cells are a heterogeneous pseudo-epithelial cell line capable of forming a variety of multicellular structures in 3D culture. We found no indication that the cells display estrogen-responsive characteristics, thus refuting previous studies which reported estrogen responsiveness. We report that MCF-12A cells are not suited for use in studies in which differential behaviors of "normal" and "cancerous" estrogen-responsive cells are to be compared.

Keywords: Estrogen response, 3D culture, Tissue morphogenesis

\section{Background}

Three-dimensional (3D) culture of breast epithelial cells has become a widely accepted and highly relevant tool

\footnotetext{
*Correspondence: ana.soto@tufts.edu

${ }^{2}$ Tufts University School of Medicine, 136 Harrison Avenue, Boston, MA 02111, USA

Full list of author information is available at the end of the article
}

for the examination of mammary gland biology $[1,2]$. Immortalized breast epithelial cells in a 3D context have contributed to a deeper understanding of breast morphogenesis including the role of its microenvironment. In this latter regard, the composition of extracellular matrix [3-5], its stiffness [6, 7], as well as collagen fiber density and organization $[4,7]$ are all relevant factors responsible for the behavior of individual cells, their intercellular 
communication, and their organization into complex multicellular structures.

From puberty onward, mammary gland structure and function are dependent on circulating hormones. Curiously, however, most mammary epithelial morphogenesis has been studied using hormone receptor-negative cell lines, such as MCF-10A. During the last decades, a number of immortalized mouse and tumorigenic humanderived mammary epithelial cell lines that express estrogen receptor alpha (ER) and display hormone sensitivity have been established and used for such a purpose; they include HC11 (mouse), MCF7, BT-474 ZR-75-B, MDAMB-361 and T47D $[8,9]$. Cells of the latter established line have recently been shown to form normal-like structures in 3D culture in response to mammotropic hormones. Exposure to estradiol alone resulted in the formation of multicellular structures while further addition of promegestone (progesterone analog) or prolactin resulted in flattened branching structures and budding structures, respectively [10]. While searching for a model that would closely resemble the human mammary tissue, we chose to test MCF-12A cells, a human mammary cell line allegedly reported to be non-tumorigenic and estrogen-responsive.

MCF-12A cells originally established at the Michigan Cancer Foundation are non-tumorigenic human cells that were derived from the reduction mammoplasty of a postmenopausal 63-year-old nulliparous woman [11]. Tissues excised from the donor's breast revealed nonmalignant fibrocystic disease containing intraductal hyperplasia abutted by dense stroma. After they were dissociated, these cells were plated for long-term culture in DMEM/H containing $<0.06 \mathrm{mM}$ calcium, later supplemented with $5 \%$ Chelex-treated equine serum and maintained for 1717 days. At this point, "passages one to 15 [were] exposed to $45{ }^{\circ} \mathrm{C}$ for as long as $72 \mathrm{~h}$ " due to an incubator malfunction. As a result of this event, most cells died. The few surviving cells were expanded and over the next 2 months sublines MCF-12A (adherent cells) and MCF-12F (floating cells) were maintained separately and became "established" [12].

During their initial characterization, MCF-12A cells were implanted subcutaneously in athymic mice, some of which were also implanted with pellets containing $17 \beta$-estradiol (E2) but no tumors developed at the inoculation sites in either groups of mice [11]. Given their origin and this outcome, the cell line was labeled as "normal". Like MCF-10A cells, and unlike tumorigenic MCF7 cells, MCF-12A cells were also considered as ER-negative and non-tumorigenic. Later, Zeillinger [13] described the expression of ER transcripts in MCF-12A as "extremely weak" and Subik [14] was not able to identify any ER positive MCF-12A cells via immunohistochemistry. At least three other studies done using MCF-12A cells described them as ER negative [15-17]. Notwithstanding, literature identifying MCF-12A cells as ER-positive gradually accrued [18-27]. In sum, diverse groups using PCR, western blots, and immunostaining have reached conflicting conclusions regarding the ER status of these cells.

Marchese et al. [28] grew MCF-12A cells in a Matrigelbased 3D model that resulted in the formation of acini and went on to show alterations in lumen formation following treatment with a variety of different estrogens. Western blots purportedly showed the expression of ER and ER-beta proteins by MCF-12A, and MCF7 cells. In addition, estradiol was reported to induce progesterone receptor (PGR) and pS2 in these cells; however, MCF$10 \mathrm{~A}$ cells were used as a control in this experiment instead of the estrogen-responsive MCF7 cells. This more recent report suggested that MCF-12A cells were a desirable tool for the study of hormone-mediated epithelial morphogenesis.

In order to test the worthiness of the MCF-12A cell line to study hormone-mediated epithelial morphogenesis, we ran experiments from which we conclude that (a) that MCF-12A cells are not responsive to estrogens, (b) the heterogeneous morphology of MCF-12A cells is due to the expansion of tightly growing epithelial colonies which gradually release populations of motile cells that generate morphologically distinct subclones, and (c) when grown in a rat-tail collagen type I matrix, MCF-12A cells produce acini and ducts, resembling those seen in the human mammary gland. Implications of these data are further discussed below.

\section{Methods}

\section{Cell maintenance}

MCF-12A (CRL-10782) and MCF-10A (CRL-10317) cells were purchased from the American Type Culture Collection (ATCC, Manassas, VA) at passage 58. As indicated by the ATCC catalog, cells were grown in Dulbecco's Modified Eagle's/F12 medium (DMEM/F12, 1:1) containing $5 \%$ equine serum (ES), $20 \mathrm{ng} / \mathrm{mL}$ epidermal growth factor, $0.5 \mu \mathrm{g} / \mathrm{mL}$ hydrocortisone, $0.1 \mu \mathrm{g} /$ $\mathrm{mL}$ cholera toxin, and $10 \mu \mathrm{g} / \mathrm{mL}$ insulin. MCF-12A cells were passaged at $<70 \%$ confluence, using a $0.25 \%(\mathrm{w} / \mathrm{v})$ trypsin- $0.03 \%(w / v)$ EDTA solution; media was replaced every 2-3 days. In our lab, MCF7 cells were grown in DMEM supplemented with $5 \%$ fetal bovine serum (FBS). For experiments intended to explore estrogenic effects in 2D culture we used phenol red-free DMEM/ F12 (1:1) containing charcoal-stripped serum which lacks endogenous estrogens. Serum was stripped using 
$5 \%$ charcoal-0.5\% Dextran T70 (CD) at $37{ }^{\circ} \mathrm{C}$ for $1 \mathrm{~h}$. Stripped fetal bovine (CD-FBS) or equine (CD-ES) serum was used for MCF7 and MCF-12A, respectively. Media formulations are listed in Table 1. All cells were maintained at $37^{\circ} \mathrm{C}$ with humidity and $6 \% \mathrm{CO}_{2}$.

\section{Immunocytochemistry}

Twenty thousand cells were plated and cultured on Nunc Thermonox plastic coverslips (Thermo Fisher) in a 24-well plate for $72 \mathrm{~h}$, washed twice with phosphate-buffered saline (PBS), and fixed in $4 \%$ formalin at room temperature for $15 \mathrm{~min}$. Coverslips were then washed twice with PBS and cells were permeabilized with $0.1 \%$ Triton X-100 at RT for 15 min. The coverslips were washed in PBS and then blocked with 1:20 goat serum in $1.5 \%$ milk for $60 \mathrm{~min}$ at RT. Primary antibodies were diluted in BC-11 (0.02 M NaPO $4 \mathrm{H}_{2}, 0.15 \mathrm{M} \mathrm{NaCl}, 0.02 \%$ Sodium Azide, 1\% BSA in distilled water) buffer and diluted antibody (Table 2) was pipetted onto parafilm before the inverted coverslips were placed on top and incubated overnight in a humid chamber at $4{ }^{\circ} \mathrm{C}$. Coverslips were washed twice with PBS, incubated for $1 \mathrm{~h}$ with appropriate peroxidase-conjugated secondary antibody diluted in $1 \%$ Bovine Serum Albumin (BSA), and visualized with 3,3'-diaminobenzidine (DAB; Sigma) after washing with PBS. Finally, coverslips were washed twice with PBS, counter stained with Harris' hematoxylin, dehydrated, and mounted on glass coverslips with Permount (Fisher Scientific).

\section{Single cell cloning}

MCF-12A cells were trypsinized and spun down at $1200 \mathrm{rpm}$ for $3 \mathrm{~min}$ on a bench-top centrifuge and the resulting cell pellet was resuspended in $5 \mathrm{~mL}$ of medium. Cells were then counted using a Beckman Coulter Z1 particle counter and diluted to 10 cells $/ \mathrm{mL}$. The diluted cell suspension was plated at $100 \mu \mathrm{L}$ per well in 96-well plates and visually scored for single cell containing wells 24-h later. Wells were assessed for different cell types and eventually expanded serially in 24-, 12- and 6-well plates.
Table 2 List of antibodies used for immunocytochemistry

\begin{tabular}{lll}
\hline & Source & Dilution \\
\hline Primary antibody & & \\
Mouse anti-E-cadherin & Novocastra & $1: 75$ \\
Mouse anti-vimentin & Novocastra & $1: 50$ \\
Mouse anti-pankeratin & Sigma & $1: 500$ \\
Rabbit anti-smooth muscle actin & Abcam & $1: 400$ \\
Mouse anti-p63 & Santa-Cruz & $1: 200$ \\
Mouse anti-beta-catenin & BD & $1: 500$ \\
Secondary antibody & & \\
Goat anti-mouse peroxidase & Pierce & $1: 1000$ \\
Goat anti-rabbit peroxidase & Pierce & $1: 1000$ \\
\hline
\end{tabular}

\section{Dose-response to estradiol (E2)}

E2 (Sigma) was diluted in ethanol at a concentration of $1 \mathrm{mM}$ and stored at $-20{ }^{\circ} \mathrm{C}$. MCF-12A cells between passages 61-66 and MCF7 cells between passages 116131 were used. Cells were plated at a density of 25,000 cells per well in 12-well plates. The next day, cells were rinsed with phenol red-free DMEM:F12 which was then replaced with phenol red-free medium plus 5\% CD-FBS (MCF7) or 5\% CD-ES (MCF-12A) containing five concentrations of E2 ( $1 \mathrm{pM}, 0.01 \mathrm{nM}, 0.1 \mathrm{nM}, 1 \mathrm{nM}, 10 \mathrm{nM})$. No E2 was added to control wells. After 5 days, cells were fixed with ice-cold $10 \%$ tricholoracetic acid and stained with sulforhodamine B (SRB). Extra dye was rinsed with $1 \%$ acetic acid then retrieved using basic Tris buffer $(\mathrm{pH}$ $10.5)$ and read at $515 \mathrm{~nm}$ absorbance [29].

\section{Estrogen-regulated gene induction assays}

MCF-12A and MCF7 cells were counted and then plated in 6-well plates at a density of 300,000 cells per well. After $24 \mathrm{~h}$, medium was removed and cells were rinsed once with rinse medium and then incubated in CD-ES or CD-FBS for an additional $24 \mathrm{~h}$. E2, diluted to 0.1 , 1 , or $10 \mathrm{nM}$ in applicable media (Table 1), was added to cells and cells were incubated at $37{ }^{\circ} \mathrm{C}$ for $48 \mathrm{~h}$. Cells were then rinsed once with sterile PBS before being lysed

Table 1 Cell culture media preparations

\begin{tabular}{|c|c|c|c|}
\hline Name & Base media & Serum & Additives \\
\hline MCF-12A/MCF-10A & DMEM/F12, 1:1 & $5 \%$ equine & $\begin{array}{l}20 \mathrm{ng} / \mathrm{mL} \text { EGF, } 0.5 \mu \mathrm{g} / \mathrm{mL} \text { hydrocortisone, } 0.1 \mu \mathrm{g} / \mathrm{mL} \\
\text { cholera toxin, } 10 \mu \mathrm{g} / \mathrm{mL} \text { insulin }\end{array}$ \\
\hline MCF7 & DMEM & $5 \%$ fetal bovine & \\
\hline Rinse & $\begin{array}{l}\text { DMEM/F12, 1:1, phenol red- } \\
\text { free }\end{array}$ & & \\
\hline CD-FBS & $\begin{array}{l}\text { DMEM/F12, 1:1, phenol red- } \\
\text { free }\end{array}$ & $\begin{array}{l}5 \% \text { charcoal-dextran stripped fetal } \\
\text { bovine }\end{array}$ & \\
\hline CD-ES & $\begin{array}{l}\text { DMEM/F12, 1:1, phenol red- } \\
\text { free }\end{array}$ & $5 \%$ charcoal-dextran stripped equine & $\begin{array}{l}20 \mathrm{ng} / \mathrm{mL} \text { EGF, } 0.5 \mu \mathrm{g} / \mathrm{mL} \text { hydrocortisone, } 0.1 \mu \mathrm{g} / \mathrm{mL} \\
\text { cholera toxin, } 10 \mu \mathrm{g} / \mathrm{mL} \text { insulin }\end{array}$ \\
\hline
\end{tabular}


according to the Qiagen RNeasy protocol. RNA was isolated and quantified with a Nanodrop photospectrometer and then $2 \mu \mathrm{g}$ of RNA was used to prepare cDNA libraries using Superscript reverse transcriptase (Invitrogen). Estrogen-responsive transcripts were quantified via qRTPCR using a SYBR green master mix (Bio-Rad) in an iQ5 thermo cycler. Fold change induction was calculated with the Bio-Rad software (version 2.1) and normalized to the expression of RPL19 transcripts. Primer sequences are shown in Table 3.

\section{$3 \mathrm{D}$ cell culture}

3D cultures were generated as previously reported [30]. Briefly, a $1 \mathrm{mg} / \mathrm{mL}$ rat-tail collagen type I solution (Corning) was made according to the manufacturer's "alternate gelation procedure" and stored on ice prior to use. Cells were detached with trypsin, pelleted at $1200 \mathrm{rpm} \times 3 \mathrm{~min}$ and then resuspended in $10 \mathrm{~mL}$ of MCF-12A medium and counted. 75,000 cells were seeded per gel per $1.5 \mathrm{~mL}$ of collagen solution in a 12 -well plate. After $30 \mathrm{~min}$ at $37^{\circ} \mathrm{C}, 2 \mathrm{~mL}$ of MCF-12A medium was added to each well and the gel was detached from the edges of the well using a sterile pipette tip. Culture medium was changed every 2-3 days and gels were harvested after 14 days. Gels were processed for paraffin embedding for histological analysis and whole mount microscopy as described in [10]. Gel diameter was measured using Axiovision (Zeiss) imaging software.

\section{Analysis of epithelial structures}

Whole mounted, carmine-stained gels were imaged at $200 \times$ with a LSM800 (Zeiss) confocal microscope. A region of interest was established $500 \mu \mathrm{m}$ inward from the apex of each semicircular gel and maintained for all replicates. An area $120 \mu \mathrm{m}$ thick was imaged using a HeNe 633 laser. The Zeiss software was used to create arrays of tiles $5 \mathrm{X} 3$ wide which were stitched together with a $20 \%$ overlap. Stitched images were then analyzed with the "Software for Automated Morphometric Analysis" (SAMA [31]) that allows for the unbiased, unsupervised analysis of physical attributes of each epithelial structure in the region of interest. Raw data produced by SAMA was filtered based on volume $\left(1000 \mu \mathrm{m}^{3}\right.$ cutoff $)$ and analyzed using Prism Software.

\section{Statistical analysis}

One-way ANOVAs were performed to compare cell proliferative effects of estradiol on MCF7 and MCF12A cells. Dunnett 2-sided t-tests were applied to analyze differences in gene expression data. Students t-tests were used to compare gel contraction. Mann-Whitney non-parametric t-tests were used to analyze 3D morphometric data derived from SAMA.

\section{Results}

\section{Description of parental cells}

After receiving frozen stocks from ATCC, MCF-12A cells were expanded in their recommended media and passaged twice. Consistent with previous publications, the cells grew as a heterogeneous population [11, 32]. A subpopulation of MCF-12A cells from this initial stock grew as colonies of cobblestone-like cells (Fig. 1a, black arrowhead). The epithelial cells were mononuclear with a well-defined nucleolus and nuclear size varied between cells within the epithelial plaques. Isolated spheroid and elongated fibroblast-like cells were observed beyond the perimeter of the epithelial colonies interspersed with domed cells (Fig. 1a, white arrowhead).

\section{Single cell cloning observations}

Based on the assumption that there were two or three subpopulations of cells within MCF-12A parental cells, single-cell cloning was performed in order to isolate the varied morphological populations. Following expansion of single-cell colonies, cobblestone-like colonies (BF9) were isolated, further expanded and frozen. These colonies contained cells of homogeneous morphology and formed large plaques with well-defined borders (Fig. 1b). After 5 passages, the edges of these colonies began to accumulate elongated cells that migrated away from the plaque. During subsequent passages, these spindleshaped cells, which briefly appear spheroid following cell division, continued to multiply and populated the spaces in between epithelial plaques. After 10 passages the initial cobblestone-like clonal population reverted to a heterogeneous population resembling the parental cell line.

An additional subpopulation was selected containing only spheroid and elongated cells types (Fig. 1c). Cells in this sub-population appeared highly motile and grew

Table 3 Estrogen responsive gene induction assay primer sequences

\begin{tabular}{|c|c|c|}
\hline Gene & Forward primer & Reverse primer \\
\hline L19 & 5'-TAGTCTGGCTTCAGCTTCCTC-3' & 5'-TCTGCAACATCCAGCTACCC-3' \\
\hline Estrogen receptor alpha & 5'-TAAATGCTGCCATGTTCCAA-3' & $5^{\prime}$-CCTGTGAGAGAACAGAAACTGG-3' \\
\hline Amphiregulin & 5'-GTGGTGCTGTCGCTCTTGATACTC-3' & 5'-TCAAATCCATCAGCACTGTGGTC-3' \\
\hline Progesterone receptors A/B & 5'-GAGGATAGCTCTGAGTCCGAGGA-3' & 5'-TTTGCCCTTCAGAAGCGG-3' \\
\hline
\end{tabular}



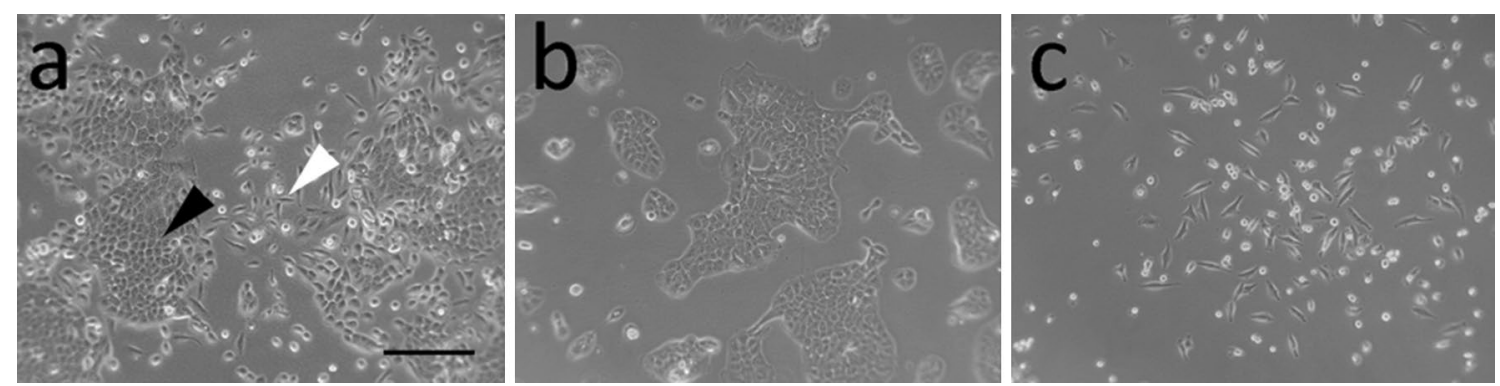

Fig. 1 MCF-12A cells grow as a heterogeneous population. Parental cells grow as epithelial plaques surrounded by single fibroblast-like and spherical cells (a). Single cell cloning lead to the isolation of epithelial-like colonies (b) and a mixed population consisting of both fibroblast-like and spheroid cells (c). (Scale bar $=250 \mu \mathrm{m}$ )

separately without forming colonies. These cloned cells failed to reestablish the cobblestone cell morphology seen in the parental line.

\section{Epithelial, myoepithelial, and mesenchymal marker expression in parental MCF-12A cells}

While several publications have alluded to the expression of some epithelial and/or mesenchymal markers by MCF-12A cells, a more thorough analysis of these cells studied under those conditions has yet to be published. MCF-12A cells did not adhere to acid-washed glass coverslips or coverslips coated with collagen or poly-lysine. Cells did, however, adhere to plastic coverslips. To investigate the cell states present in MCF-12A cultures, a panel of epithelial and mesenchymal markers was employed. MCF-10A cells were used as a positive control for epithelial cell markers. The epithelial sub-population of MCF-12A expressed E-cadherin diffusely throughout the cells with darker staining localized to cell-cell junctions
(Fig. 2) while their elongated fibroblast-like counterparts failed to express E-cadherin (Fig. 2). Expression of E-cadherin at cell-cell junctions was more pronounced in the center of epithelial plaques and diminished in between peripheral cells. MCF-12A cells also expressed vimentin. Remarkably, cells at the epithelial plaque edges showed accumulations of vimentin radiating away from the plaques center, and vimentin was excluded from areas of cell-cell contact (Fig. 2, arrowhead). Cells separated from epithelial plaques expressed vimentin throughout their cytoplasm. As expected, vimentin expression was absent from control MCF-10A cells.

Cytokeratins were expressed in all MCF-12A cells. Beta-catenin was expressed throughout, though strongly at cell-cell interfaces, but not in the nuclei of cells within epithelial plaques formed by both MCF10A cells and MCF-12A cells. However, MCF-12A cells growing isolated from plaques contained beta-catenin throughout their cytoplasm and in their nucleus in some smaller

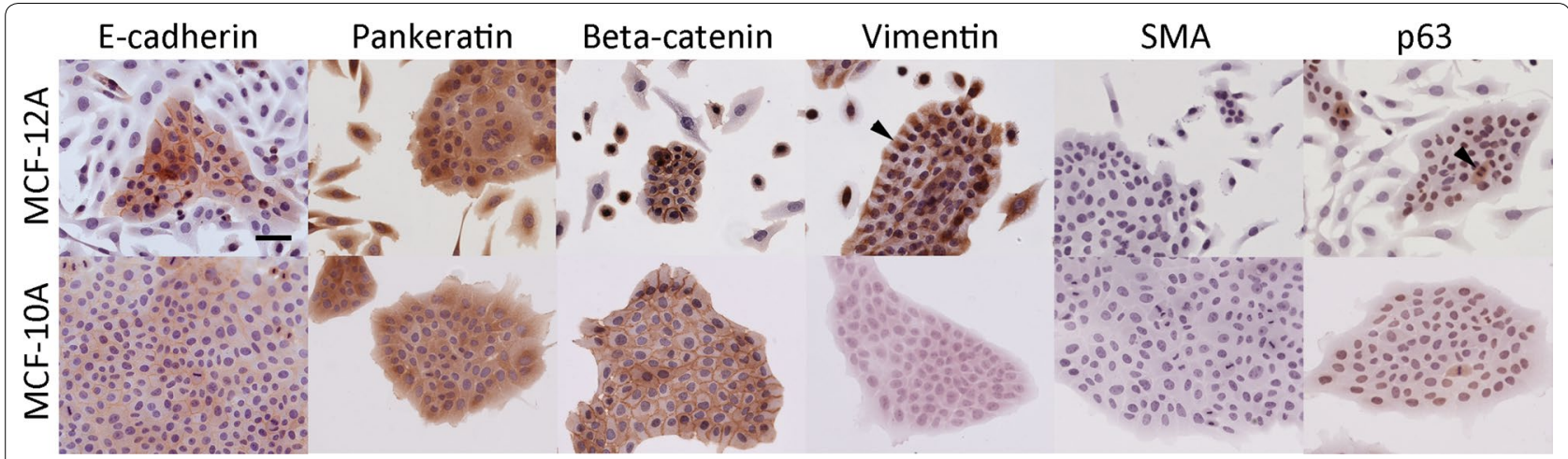

Fig. 2 MCF-12A cells express epithelial and mesenchymal cell markers. E-cadherin is expressed throughout plaque-associated cells and highly localized to cell-cell junctions in the center of epithelial plaques. Localization at cell-cell junctions decreases at plaque edges. Cytokeratins are expressed in all MCF-12A subtypes. Beta-catenin is expressed by epithelial-like MCF-12A colonies with increased localization at their cell-cell junctions and dispersed throughout the cytoplasm of fibroblast-like and spheroid cells. Vimentin is expressed in the cytoplasm of all cells but concentrated in fan-like projections from peripheral cells. P63 is expressed in dividing cells but absent from others. MCF-10A cells used as a control for epithelial marker expression. Scale bar $=100 \mu \mathrm{m}$ 
cells. Despite their appearance, elongated fibroblast-like MCF-12A cells did not express the myoepithelial marker smooth muscle actin (Fig. 2). The myoepithelial cell marker p63 was expressed in the nucleus of epitheliallike MCF-12A cells and in the cytoplasm of dividing cells within the epithelial plaques. This distribution of p63 expression is similar to that seen in colonies of MCF10A cells (Fig. 2, lower right). MCF-12A cells growing away from epithelial plaques, however, lacked expression of p63 in both their nucleus and cytoplasm.

\section{MCF-12A cells proliferate equally with or without E2}

ER-positive MCF7 and T47D cells have been shown to exhibit a proliferative dose response to E2 when cultured in medium containing CD stripped serum-supplemented medium, and are inhibited from proliferating by a serumborne inhibitor [33]. This represents a standard case for studying the proliferative effects of E2 [34]. Thus, had MCF-12A cells been shown to be ER-positive, enhanced proliferation of these cells in the presence of estrogens accompanied by quiescence in medium supplemented with $\mathrm{CD}$-stripped serum would have indicated the functionality of the ER. However, as shown in Fig. 3a, while MCF7 cells proliferated maximally in E-stripped serum supplemented with $0.1 \mathrm{nM}$ E2 and did not proliferate under 5\% CD-FBS conditions, MCF-12A cells proliferated maximally regardless of whether the cells were exposed to CDFBS or to CDFBS plus E2. These results indicated that MCF-12A cells were not influenced in their proliferative behavior by the presence of CDFBS or of $\mathrm{E} 2$ in the culture medium.

\section{MCF-12A cells lack expression of ER and its transcriptional targets}

The proliferative response of MCF7 cells to E2 was accompanied by a decrease in the expression of ER transcripts (Fig. 3b). In CD-FBS media, MCF7 cells expressed ER transcripts $\geq 250$-fold higher than MCF-12A cells when maintained in a comparable medium. Increasing concentrations of E2 resulted in decreased expression
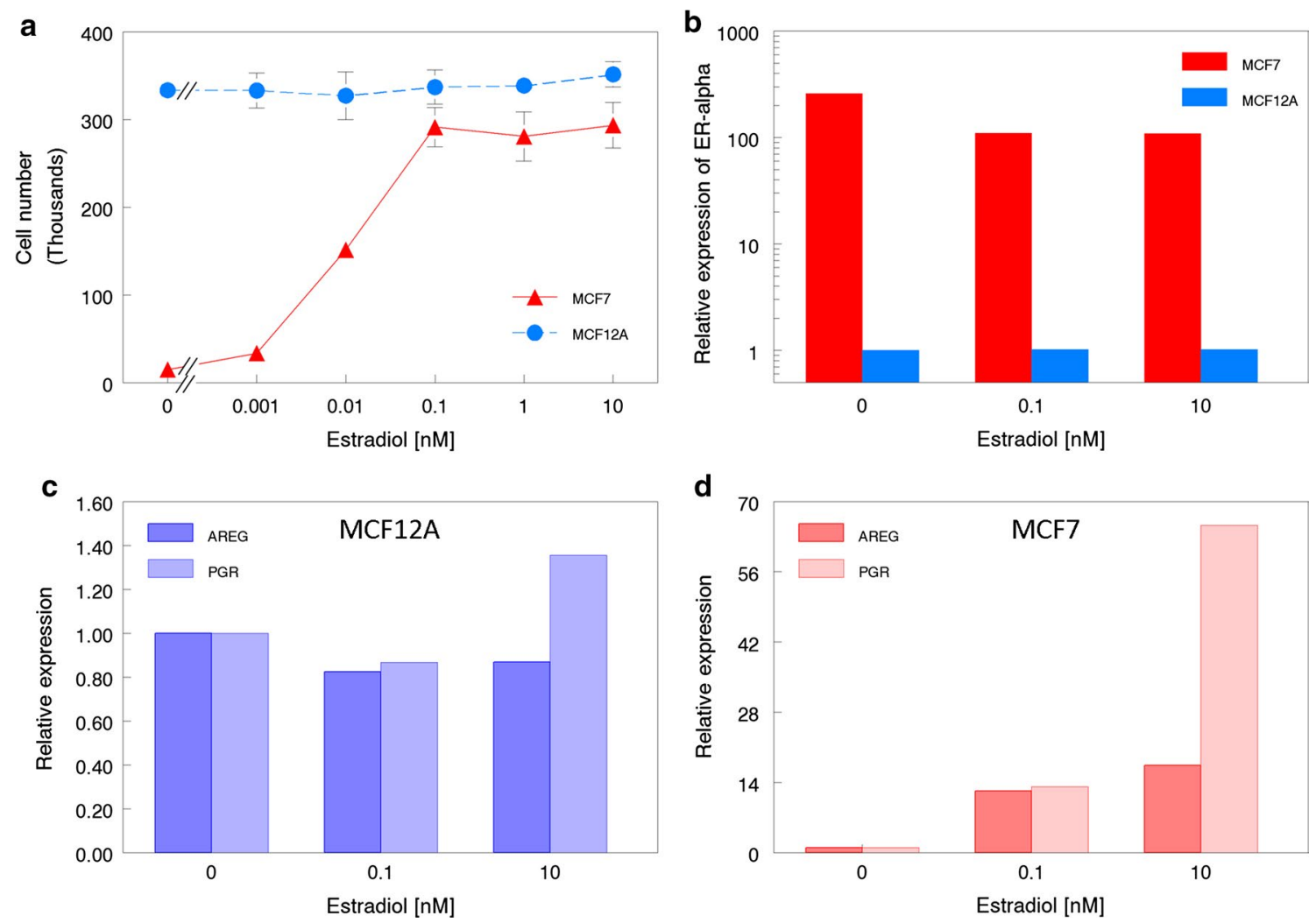

Fig. 3 MCF-12A cells do not respond to stimulation by estradiol. MCF-12A cells proliferate maximally under all experimental conditions while MCF7 cell proliferation is inhibited in the absence of estradiol and stimulated at increasing concentrations (a). Relative to MCF7 cells, MCF-12A cells do not express estrogen receptor alpha (b). The induction of estrogen responsive genes amphiregulin (AREG) and progesterone receptor (PGR) is not seen in MCF-12A (c) cells while estrogen receptor alpha-positive MCF7 cells show expression following estradiol exposure (d). Note differences in y-axis scales to accommodate variation in expression differences 
of ER transcripts by MCF7 cells but had no effect on the expression by MCF-12A cells. We next attempted to determine whether or not there was transcriptional activation by ER in MCF-12A. The expression of progesterone receptor (PGR) and amphiregulin (AREG) by MCF12A cells showed no estrogen-dependent induction (Fig. 3c), unlike that observed in MCF7 cells (Fig. 3d). The $y$-axis scales highlight the magnitude of transcript expression differences between the cell lines.

\section{MCF-12A cells form ducts and acini in 3D}

To study MCF-12A morphogenesis in 3D, we employed an embedded; floating rat-tail collagen type I culture system. When examined 14 days after seeding, MCF-12A cells showed multiple phenotypes. The majority of them were solid spherical structures varying in size (Fig. 4a). Acini with single-cell thick borders and cleared lumena were observed (Fig. 4b). MCF-12A cells also formed branching, ductal structures (Fig. 4c), of which some showed lumen (Fig. 4d). Spherical clusters of concentric cells (Fig. 4c, arrow) were often seen within ductal structures. In addition to multicellular structures, spindleshaped single cells grew throughout the gel.

Addition of parental MCF-12A cells caused collagen gels to contract compared to acellular gels after 14 days (Fig. 5). BF9 cells contracted gels to a similar degree.

\section{MCF-12A morphogenesis varies due to cell-subtype dynamics}

Because of the unique 2D phenotypes of the two cellular subtypes isolated from MCF-12A parental cells, we asked

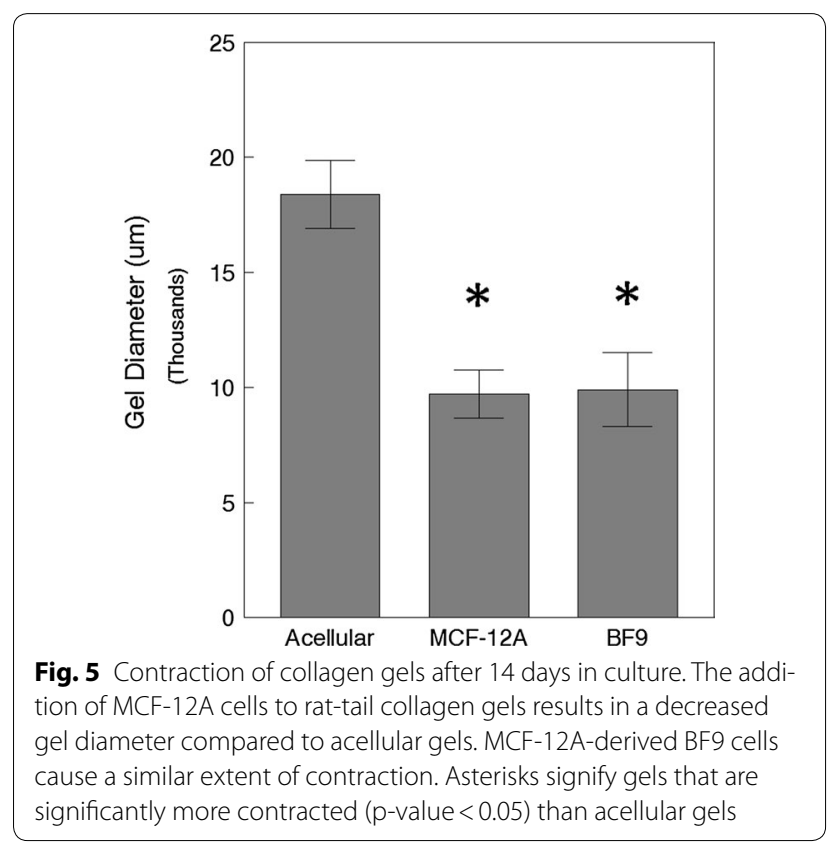

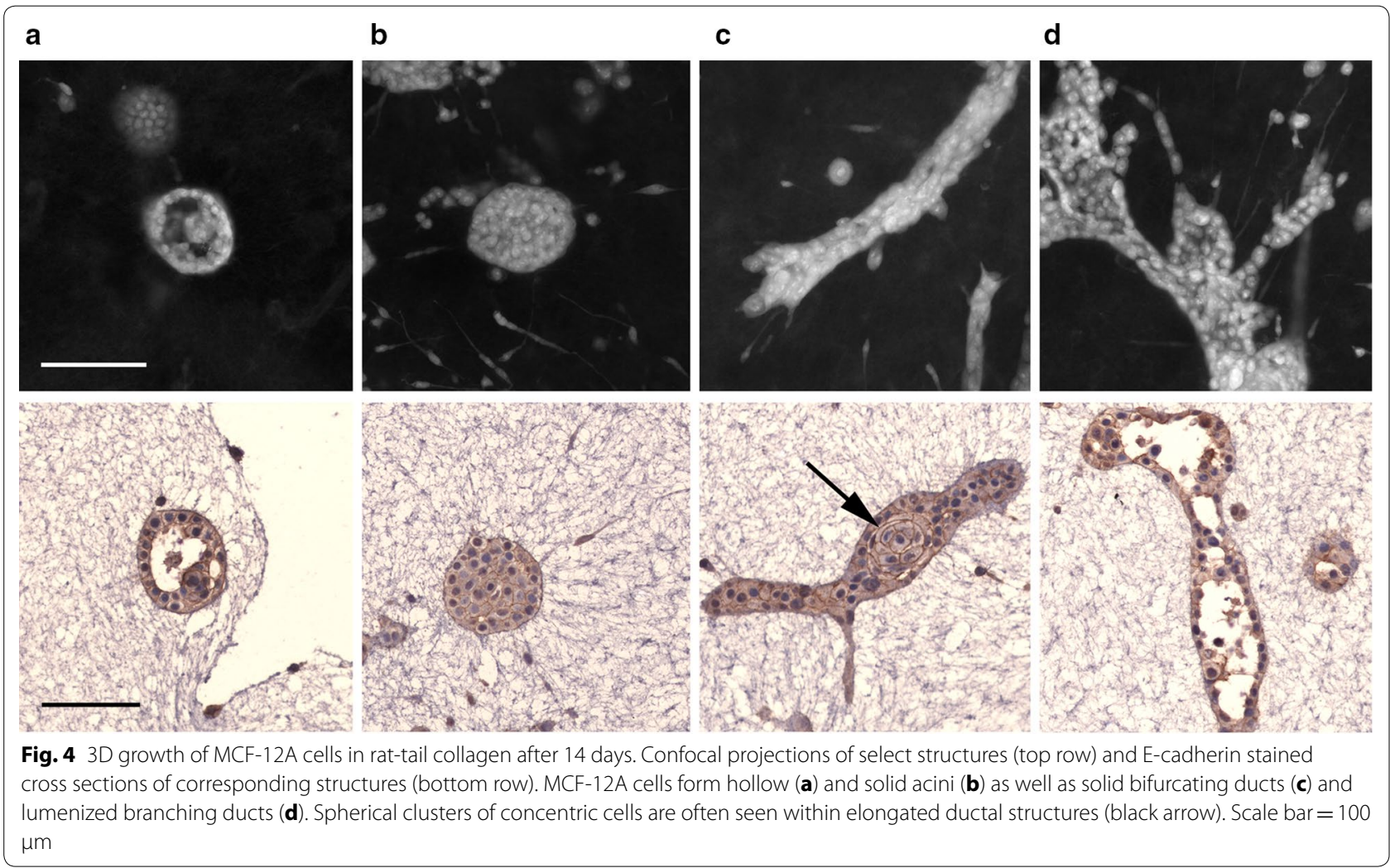


whether or not the epithelial-like populations could form different structures in 3D. We were specifically interested in observing complex, multicellular epithelial structures. Therefore, the SAMA data was analyzed with filters in place to ignore single cells and non-relevant entities, such as sheets of cells or gel artifacts. All structures below $1000 \mu \mathrm{m}^{3}$ were removed prior to statistical analysis. As shown in Fig. 6, structures formed by BF9 cells are longer ( $p$-value $\leq 0.0001)$ and flatter $(p$-value $=0.0007)$ on average than those found in parental cell gels. Conversely, MCF-12A structures were more spherical structures on average ( $p$-value $\leq 0.0001)$. These parameters were also statistically significantly different at the $500 \mu \mathrm{m}^{3}$ (except flatness) and $2000 \mu^{3}$ cutoffs (data not shown).

\section{Discussion}

Hormonal regulation of morphogenesis has been explored in a few established culture models that use immortalized cell lines such as MCF7 and T47D [10, 35]. Initially, we were interested in employing the MCF$12 \mathrm{~A}$ cells in our $3 \mathrm{D}$ culture model due to their normal, non-tumorigenic origin and their alleged estrogen sensitivity. To our knowledge, currently, no "normal", ERpositive established cell lines are available. Claims of estrogen-sensitivity made about MCF-12A cells appealed to us for the exploration of the human mammary gland in both normal development and in pathological contexts, like carcinogenesis. It is acknowledged, however, that a given cell line often varies widely in hormone receptor content from one lab to the next [36-38]. Thus, before embarking in an extended study of the subject it was necessary to accurately characterize the cell line to be used in such a project.

\section{Morphology and cell-type markers}

Unlike MCF-10A cells, which form epithelial plaques with smooth, defined boarders in 2D cultures, MCF-12A cells underwent a process of phenotypic changes during their propagation. Namely, cells at the edge of plaques lost the plasma membrane localization of E-cadherin and beta-catenin, altered their distribution of vimentin, and became highly motile. Morphologically, these cells

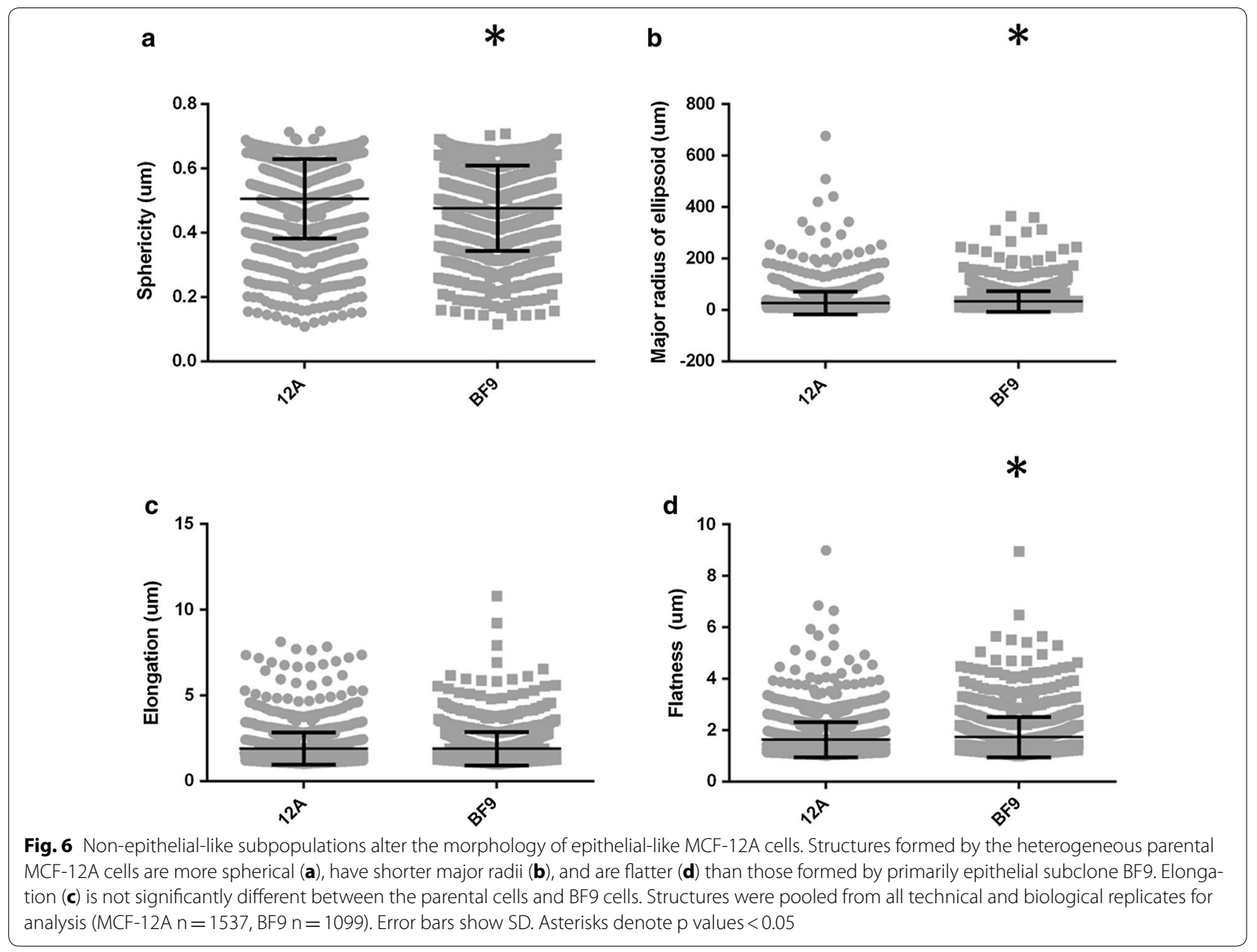


appeared to be migrating away from the plaques due to their fan-like projections (Fig. 2). A possible explanation for the dynamic morphologies seen in MCF-12A cells would have been the co-expression of E-cadherin and vimentin. An inverse relationship between E-cadherin and vimentin in intact tissues is considered to be an indicator of epithelial-mesenchymal switching [39]. When vimentin was overexpressed in MCF7 cells they adopted mesenchymal morphologies with vimentin localized within the cells in a pattern similar to that seen at the edges of MCF-12A cell colonies [40]. Apparently, the mechanical and biochemical constraints imposed upon MCF-12A cells growing at the center of epithelial plaques are reduced on cells residing in the plaque's periphery.

MCF-12A cells express gene products that are associated with both luminal and basal subtypes and have features of basal progenitor cells [41]. Dual expression of E-cadherin and vimentin has been linked to highly aggressive tumors in other tissues including those in the lung and neck [42, 43]. However, MCF-12A cells are considered non-invasive [11]. Expression of p63 has been reported to be restricted to the basal layer of complex glands such as the mammary gland and prostate $[44,45]$. Decreasing p63 expression in these cells was linked to a need to replenish cells composing the luminal compartment. The finding that p63-/- mice lack stratified epithelium would support this notion [46]. The transient expression of p63 in dividing epithelial-like MCF-12A and MCF-10A cells is likely to affect the behavior of their daughter cells. However, non-epithelial MCF-12A cells do not express p63 (Fig. 2), further questioning the cell type that MCF-12A cells more closely resemble in vivo.

\section{Estrogenicity}

Until now, the estrogen responsive profile of MCF-12A has been ambiguous. In the original report, MCF-12A xenografts failed to grow in the presence of $\mathrm{E} 2$ and additional findings, mentioned but not shown by the authors, suggested that the cells may have been ER-negative [11]. The expression of ER is not sufficient to describe a cell line as being responsive to estrogens. Nevertheless, published reports claimed these cells to be ER positive and have therefore been used as normal controls to genuine estrogen-responsive cancer cells. Mischaracterizations such as these lead to contradictory conclusions and may have added to the increasingly poor reproducibility of biomedical studies [47]. By using multiple assays, here we have now shown that MCF-12A cells are unresponsive to E2 in culture conditions, both in regard to the controls of cell proliferation and of the expression of estrogen-regulated genes.

Estrogen responsive cells remain quiescent in the presence of charcoal-stripped serum and the absence of E2 and proliferate in the presence of estrogenic compounds [48]. The proliferative effect of estrogen on these cells only becomes effective when serum supplemented to the basic cell culture medium is CD stripped; in this condition, cells enter proliferative quiescence due to the effect of the serum-borne inhibitor, albumin [33, 49]. Addition of physiological levels of estradiol neutralize the inhibitory effect of $C D$ serum and thus the capacity of these cells to proliferate is restored. Instead, MCF-12A cells proliferated equally well regardless of the media's estrogen content. This implies that MCF-12A cells are insensitive to $C D$-serum induced quiescence and thus are non-responsive to both the serum-borne inhibitor and to estradiol.

In order to explore whether the lack of proliferative response to E2 was due to absence of ER, we tested transcriptional activation resulting from estradiol-ER binding to estrogen responsive cells (MCF7) and compared it to that of MCF-12A cells. The binding of estrogenic chemicals to ER affected the induction and/or attenuation of different transcripts within MCF7 cells [50]. We used qRT-PCR to investigate the induction of estrogenresponsive genes in MCF7 cells by adding estradiol concentrations that resulted in maximal proliferative responses. While the expression of both amphiregulin and progesterone receptor was significantly increased in MCF7 cells treated with estradiol, MCF-12A fail to significantly express either gene product following $48 \mathrm{~h}$ of estradiol stimulation. These results imply that, in addition to the lack of a proliferative response by estrogens, exposure to estrogens also failed to induce specific gene transcription in MCF-12A cells. Moreover, relative to MCF7 cells, MCF-12A cells express levels of ER transcripts similar to those seen in ER-negative cell lines. The basal-like transcriptional profile of MCF-12A cells further suggests that these cells are ER negative, as only luminal cells express ER in tissues [51].

\section{Growth in 3D}

The formation of epithelial structures in 3D culture allows for the in vitro study and manipulation of the mammary epithelium. We have previously shown that some cell lines form both acini and ducts when grown in collagen with and without the addition of Matrigel $[30,52]$. Herein, we examined the capacity of MCF-12A cells to form normal epithelial tissue structures. In a 3D context, the formation of lumena is a hallmark of normal mammary phenotype [5]. When grown on top of laminin-rich extracellular matrix for 4 days, MCF-12A cells formed rounded, non-lumenized structures [41]. Using a similar cell model, these early round structures were shown to form growth-arrested acini consisting of polarized cells after 16 days in culture [28]. After 14 days 
of being embedded in rat-tail type I collagen, in addition to lumenized acini and solid, round structures, MCF$12 \mathrm{~A}$ cells in our growth conditions organized into large, lumenized, branching structures. The formation of ductlike structures by MCF-12A cells has previously been described only when grown on top of matrix derived from nulliparous rat mammary glands [53]. This implies that rat-tail type 1 collagen recapitulates the mammary gland environment found in vivo better than in several other 3D models currently in use. The rounded clusters of concentric cells (Fig. 4c, arrow) never occurred outside of other structures implying that their formation is dependent on the interruption of interactions between those cells and the collagen matrix. MCF-10A cells grown in rat-tail type I collagen only form acini and short non-branching ducts without any "rosebud" structures.

\section{SAMA as a tool to analyze epithelial structures grown in 3D culture}

We employed the SAMA package for the unbiased, unsupervised analysis of MCF-12A structures formed in collagen gels. SAMA allows for unsupervised, and hence unbiased and automated measurements of a host of biologically relevant physical parameters of epithelial structures, an ability that is useful in analyzing large number of structures. Another of the advantages of the SAMA software is the ability to filter the data based on both size and biological relevance of the structures analyzed. This software package enabled us to analyze hundreds of structures within a 3D space for geometric parameters that otherwise would have been difficult to perform.

The variability of structural shapes formed in other areas of these gels may be due to the distribution of MCF-12A cells migrating toward the perimeter of each gel. The ability of MCF-12A to drastically contract the gels (Fig. 5) and the heterogeneous collagen fiber organization may be responsible for this variability [30]. Gel contraction of similar magnitude has been previously described when MCF-10A cells were grown in rat-tail collagen and resulted in a non-homogenous distribution of structures [30]. The finding that fibroblast-like celldepleted BF9 subclone contracted gels at a similar degree to that seen by the parental cell population implies that those non-epithelial-like cells do not contribute to gel contraction. If those cells were responsible for increased gel contraction, assuming their contributions to be additive, BF9 gels would be expected to contract to a degree intermediate between acellular and parental gels.

The results of SAMA analysis confirm that MCF-12A parental cells form spherical, acinar and duct-like structures. Upon removal of the MCF-12A cells which grow away from the epithelial plaques in $2 \mathrm{D}$, the remaining cells form longer, flatter structures than those produced by the heterogeneous parental cell line, on average. The differences seen between parental and BF9 gels are not simply due to the exclusion of individual spindle-shaped cells but, rather, imply an interaction between the two cell types in 3D which results in distinctly different structural compositions. Human fibroblasts have been shown to speed up the morphogenesis of epithelial structures formed by MCF-10A cells and increase the number and length of ducts formed when seeded jointly in collagen gels; this effect is likely due to fibroblast-mediated formation of thicker, parallel collagen fibers [4, 54]. However, the single cell population of MCF-12A acts differently than fibroblasts; this effect might be due to fibroblasts interfering with the ability of the epithelial cells to alter collagen organization leaving thinner, less organized fibers favoring the formation of rounded acinar structures.

\section{Conclusions}

We have documented that MCF-12A cells are a nontumorigenic, heterogeneous, estrogen receptor-negative cell line that express a combination of epithelial and mesenchymal markers. In floating rat-tail type I collagen gels, MCF-12A cells form complex, lumenized acini and ducts, the characteristics and distribution of which are altered by either the presence or absence of different subpopulations. Based on the time-dependent progressive population changes within the parental cell line and the complex interactions between these two cell types in 3D, MCF-12A cells appear unsuitable for use in epithelial morphogenesis studies when compared to MCF10A cells.

\section{Abbreviations}

AREG: amphiregulin; CD: charcoal dextran; E2: 17-beta estradiol; ER: estrogen receptor alpha; ES: equine serum; FBS: fetal bovine serum; PGR: progesterone receptor.

\section{Authors' contributions}

MS generated all figures and the body of the manuscript. CS and AS provided significant intellectual contributions to the design of the study and the interpretation of its findings. All authors read and approved the final manuscript.

\section{Author details}

1 Sackler School of Graduate Biomedical Sciences, Tufts University, 136 Harrison Avenue, Boston, MA 02111, USA. ${ }^{2}$ Tufts University School of Medicine, 136 Harrison Avenue, Boston, MA 02111, USA.

\section{Acknowledgements}

We greatly appreciate the technical and editorial contributions of Cheryl Schaeberle, Lucia Speroni, Maël Montévil, and Nafis Hasan.

\section{Competing interests}

The authors declare that they have no competing interests.

\section{Availability of data and materials}

The datasets generated during the current study are available from the corresponding author upon reasonable request. 


\section{Consent for publication}

Not applicable.

\section{Ethics approval and consent to participate}

Not applicable.

\section{Funding}

Support was provided by Award Number ES08314 (P.I. AMS) from the U.S National Institute of Environmental Health Sciences. The funders had no role in the study design, data collection and analysis, decision to publish, or preparation of the manuscript.

\section{Publisher's Note}

Springer Nature remains neutral with regard to jurisdictional claims in published maps and institutional affiliations.

Received: 20 November 2017 Accepted: 5 March 2018 Published online: 20 March 2018

\section{References}

1. Hebner C, Weaver VM, Debnath J. Modeling morphogenesis and oncogenesis in three-dimensional breast epithelial cultures. Annu Rev Pathol. 2008:3:313-39.

2. Montévil M, Speroni L, Sonnenschein C, Soto AM. Modeling mammary organogenesis from biological first principles: cells and their physical constraints. Prog Biophys Mol Biol. 2016;122:58-69.

3. Schedin P, Mitrenga T, McDaniel S, Kaeck M. Mammary ECM composition and function are altered by reproductive state. Mol Carcinog. 2004:41:207-20.

4. Dhimolea E, Soto AM, Sonnenschein C. Breast epithelial tissue morphology is affected in 3D cultures by species-specific collagen-based extracelIular matrix. J Biomed Mater Res A. 2012;100:2905-12.

5. Krause S, Maffini MV, Soto AM, Sonnenschein C. The microenvironment determines the breast cancer cells' phenotype: organization of MCF7 cells in 3D cultures. BMC Cancer. 2010;10:263-75.

6. Paszek MJ, Zahir N, Johnson KR, Lakins JN, Rozenberg Gl, Gefen A, Reinhart-King CA, Margulies SS, Dembo M, Boettiger D, Hammer DA, Weaver VM. Tensional homeostasis and the malignant phenotype. Cancer Cell. 2005;8:241-54.

7. Barnes C, Speroni L, Quinn K, Montévil M, Saetzler K, Bode-Animashaun G, McKerr G, Georgakoudi I, Downes S, Sonnenschein C, Howard CV, Soto AM. From single cells to tissues: interactions between the matrix and human breast cells in real time. PLoS ONE. 2014;9:e93325.

8. Lacroix M, Leclercq G. Relevance of breast cancer cell lines as models for breast tumours: an update. Breast Cancer Res Treat. 2004;83:249-89.

9. Neve RM, Chin K, Fridlyand J, Yeh J, Baehner FL, Fevr T, Clark L, Bayani N, Coppe JP, Tong F, Speed T, Spellman PT, DeVries S, Lapuk A, Wang NJ, Kuo WL, Stilsell JL, Pinkel D, Albertson DG, Waldman FM, McCormick F, Dickson RB, Johnson MD, Lippman M, Ethier S, Gazdar A, Gray JW. A collection of breast cancer cell lines for the study of functionally distinct cancer subtypes. Cancer Cell. 2006;10:515-27.

10. Speroni L, Whitt GS, Xylas J, Quinn KP, Jondeau-Cabaton A, Georgakoudi I, Sonnenschein C, Soto AM. Hormonal regulation of epithelial organization in a 3D breast tissue culture model. Tissue Eng Part C Methods. 2014;20:42-51.

11. Paine TM, Soule HD, Pauley RJ, Dawson PJ. Characterization of epithelial phenotypes in mortal and immortal human breast cells. Int J Cancer. 1992;50:463-73.

12. Pauley RJ. (1993) Immortal human mammary epithelial cell sublines. US Patent 5,206,165, 27 April 1993.

13. Zeillinger R, Tantscher E, Schneeberger C, Tschugguel W, Eder S, Sliutz G, Huber JC. Simultaneous expression of nitric oxide synthase and estrogen receptor in human breast cancer cell lines. Breast Cancer Res Treat. 1996:40:205-7.

14. Subik K, Lee JF, Baxter L, Strzepek T, Costello D, Crowley P, Xing L, Hung MC, Bonfiglio T, Hicks DG, Tang P. The expression patterns of ER, PR, HER2,
CK5/6, EGFR, Ki-67 and AR by immunohistochemical analysis in breast cancer cell lines. Breast Cancer (Auckl). 2010:4:35-41.

15. Elangovan S, Ramachandran S, Venkatesan N, Ananth S, Gnana-Prakasam JP, Martin PM, Browning DD, Schoenlein PV, Prasad PD, Ganapathy V, Thangaraju M. SIRT1 is essential for oncogenic signaling by estrogen/ estrogen receptor a in breast cancer. Cancer Res. 2011;71:6654-64.

16. Stander XX, Stander BA, Joubert AM. In vitro effects of an in silico-modelled $17 \beta$-estradiol derivative in combination with dichloroacetic acid on MCF-7 and MCF-12A cells. Cell Prolif. 2011:44:567-81.

17. Zhang X, Harrington N, Moraes RC, Wu MF, Hilsenbeck SG, Lewis MT. Cyclopamine inhibition of human breast cancer cell growth independent of Smoothened (Smo). Breast Cancer Res Treat. 2009;115:505-21.

18. Engel N, Opperman C, Falodun A, Kragl U. Proliferative effects of five traditional Nigerian medicinal plant extracts on human breast and bone cancer cell lines. J Ethnopharmacol. 2011;137:1003-10.

19. Eisen SF, Brown HA. Selective estrogen receptor (ER) modulators differentially regulate phospholipase $D$ catalytic activity in ER-negative breast cancer cells. Mol Pharmacol. 2002;62:911-20.

20. Wu J, Omene C, Karkoszka J, Bosland M, Eckard J, Klein CB, Frenkel K. Caffeic acid phenethyl ester (CAPE), derived from a honeybee product propolis, exhibits a diversity of anti-tumor effects in pre-clinical models of human breast cancer. Cancer Lett. 2011:308:43-53.

21. Dai J, Jian J, Bosland M, Frenkel K, Bernhardt G, Huang X. Roles of hormone replacement therapy and iron in proliferation of breast epithelial cells with different estrogen and progesterone receptor status. Breast. 2008; 17:172-9.

22. Mitropoulou TN, Tzanakakis GN, Kletsas D, Kalofonos HP, Karamanos NK. Letrozole as a potent inhibitor of cell proliferation and expression of metalloproteinases (MMP-2 and MMP-9) by human epithelial breast cancer cells. Int J Cancer. 2003;104:155-60.

23. Kousidou OC, Roussidis AE, Theocharis AD, Karamanos NK. Expression of MMPs and TIMPs genes in human breast cancer epithelial cells depends on cell culture conditions and is associated with their invasive potential. Anticancer Res. 2004;24:4025-30.

24. Kousidou OC, Tzanakarkis GN, Karamanos NK. Effects of the natural isoflavonoid genistein on growth, signaling pathways and gene expression of matrix macromolecules by breast cancer cells. Mini Rev Med Chem. 2006:6:331-7.

25. Arif JM, Kunhi M, Subramanian MP, Al-Khodairy F. Cytotoxic and genotoxic potentials of newly synthesized antiviral aminopyrazoloquinoline derivatives. Med Chem Res. 2008;17:297-304.

26. Al-Souhibani N, Al-Ahmadi W, Hesketh JE, Blackshear PJ, Kahbar KS. The RNA-binding zinc-finger protein tristetraprolin regulates AU-rich mRNAs involved in breast cancer-related processes. Oncogene. 2010;29:4205-15.

27. Gelfand R, Vernet D, Bruhn K, Vadgama J, Gonzalez-Cadavid NF. Longterm exposure of MCF-12A normal human breast epithelial cells to ethanol induces epithelial mesenchymal transition and oncogenic features. Int J Oncol. 2016:48:2399-414

28. Marchese S, Silva E. Disruption of 3D MCF-12A breast cell cultures by estrogens - an in vitro model for ER-mediated changes indicative of hormonal carcinogenesis. PLoS ONE. 2012;7:e45767.

29. Vichai V, Kirtikara K. Sulforhodamine B colorimetric assay for cytotoxicity screening. Nat Protoc. 2006:1:1112-6.

30. Dhimolea E, Maffini MV, Soto AM, Sonnenschein C. The role of collagen reorganization on mammary epithelial morphogenesis in a 3D culture model. Biomaterials. 2010;31:3622-30.

31. Paulose T, Montévil M, Speroni L, Sonnenschein C, Soto AM. SAMA: a method for 3D morphological analysis. PLoS ONE. 2016;11:e0153022.

32. Schedin PJ, Eckel-Mahan KL, McDaniel SM, Prescott JD, Brodsky KS, Tentler JJ, Gutierrez-Hartmann A. ESX induces transformation and functional epithelial to mesenchymal transition in MCF-12A mammary epithelial cells. Oncogene. 2004:23:1766-79.

33. Sonnenschein C, Soto AM, Michaelson CL. Human serum albumin shares the properties of estrocolyone-l, the inhibitor of the proliferation of estrogen-target cells. J Steroid Biochem Mol Biol. 1996;59:147-54.

34. Soto AM, Sonnenschein C, Chung KL, Fernandez MF, Olea N, OleaSerrano MF. The E-SCREEN assay as a tool to identify estrogens: an update on estrogenic environmental pollutants. Environ Health Perspect. 1995;103:113-22 
35. Barcus CE, Holt EC, Keely PJ, Eliceiri KW, Schuler LA. Dense collagen-I matrices enhance pro-tumorigenic estrogen-prolactin crosstalk in MCF-7 and T47D breast cancer cells. PLoS ONE. 2015;10:e0116891.

36. Burdall SE, Hanby AM, Lansdown MR, Speirs V. Breast cancer cell lines: friend or foe? Breast Cancer Res. 2003:5:89-95.

37. Osborne CK, Hobbs K, Trent JM. Biological differences among MCF-7 human breast cancer cell lines from different laboratories. Breast Cancer Res Treat. 1987;9:111-21.

38. Villalobos M, Olea N, Brotons JA, Olea-Serrano MF, Ruiz de Almodovar JM, Pedraza V. The E-screen assay: a comparison of different MCF7 cell stocks. Environ Health Perspect. 1995:103:844-50.

39. Toivola DM, Tao GZ, Habtezion A, Liao J, Omary MB. Cellular integrity plus: organelle-related and protein-targeting functions of intermediate filaments. Trends Cell Biol. 2005;15:608-17.

40. Mendez MG, Kojima S, Goldman RD. Vimentin induces changes in cell shape, motility, and adhesion during the epithelial to mesenchymal transition. FASEB J. 2010;24:1838-51.

41. Kenny PA, Lee GY, Myers CA, Neve RM, Semeiks JR, Spellman PT, Lorenz K, Lee EH, Barcellos-Hoff MH, Petersen OW, Gray JW, Bissell MJ. The morphologies of breast cancer cell lines in three-dimensional assays correlate with their profiles of gene expression. Mol Oncol. 2007;1:84-96.

42. Yagasaki R, Noguchi M, Minami M, Earashi M. Clinical significance of E-cadherin and vimentin co-expression in breast cancer. Int J Oncol. 1996:9:755-61.

43. Nijkamp MM, Span PN, Hoogsteen IJ, van der Kogel AJ, Kaanders JH, Bussink J. Expression of E-cadherin and vimentin correlates with metastasis formation in head and neck squamous cell carcinoma patients. Radiother Oncol. 2011;99:344-8.

44. Forster N, Saladi SV, van Bragt M, Sfondouris ME, Jones FE, Li Z, Ellisen LW. Basal cell signaling by p63 controls luminal progenitor function and lactation via NRG1. Dev Cell. 2014:28:147-60.
45. Signoretti S, Waltregny D, Dilks J, Isaac B, Lin D, Garraway L, Yang A, Montironi R, McKeon F, Loda M. p63 is a prostate basal cell marker and is required for prostate development. Am J Pathol. 2000;157:1769-75.

46. Yang A, Schweitzer R, Sun D, Kaghad M, Walker N, Bronson RT, Tabin C, Sharpe A, Caput D, Crum C, McKeon F. p63 is essential for regenerative proliferation in limb, craniofacial and epithelial development. Nature. 1999:398:714-8.

47. Horbach S, Halffman W. The ghosts of HeLa: how cell line misidentification contaminates the scientific literature. PLOS ONE. 2017:12:e0186281.

48. Soto AM, Sonnenschein C. The role of estrogens on the proliferation of human breast tumor cells (MCF-7). J Steroid Biochem. 1985;23:87-94.

49. Soto AM, Silvia RM, Sonnenschein C. A plasma-borne specific inhibitor of the proliferation of human estrogen-sensitive breast tumor cells (estrocolyone-I). J Steroid Biochem Mol Biol. 1992;43:703-12.

50. Coser KR, Chesnes J, Hur J, Ray S, Isselbacher KJ, Shioda T. Global analysis of ligand sensitivity of estrogen inducible and suppressible genes in MCF7/BUS breast cancer cells by DNA microarray. Proc Nat Acad Sci USA. 2003:100:13994-9.

51. Sleeman KE, Kendrick H, Robertson D, Isacke CM, Ashworth A, Smalley MJ. Dissociation of estrogen receptor expression and in vivo stem cell activity in the mammary gland. J Cell Biol. 2007;176:19-26.

52. Krause $S$, Jondeau-Cabaton A, Dhimolea E, Soto AM, Sonnenschein C, Maffini MV. Dual regulation of breast tubulogenesis using extracellular matrix composition and stromal cells. Tissue Eng Part A. 2012;18:520-32.

53. McDaniel SM, Rumer KK, Biroc SL, Metz RP, Singh M, Porter W, Schedin P. Remodeling of the mammary microenvironment following lactation promotes breast tumor cell metastasis. Am J Pathol. 2006;168:608-20.

54. Krause S, Maffini MV, Soto AM, Sonnenschein C. A novel $3 D$ in vitro culture model to study stromal-epithelial interactions in the mammary gland. Tissue Eng Part C Methods. 2008;14:261-71.

\section{Submit your next manuscript to BioMed Central and we will help you at every step:}

- We accept pre-submission inquiries

- Our selector tool helps you to find the most relevant journal

- We provide round the clock customer support

- Convenient online submission

- Thorough peer review

- Inclusion in PubMed and all major indexing services

- Maximum visibility for your research

Submit your manuscript at www.biomedcentral com/submit 